\title{
FATTY ACID COMPOSITION OF COMMERCIALLY IMPORTANT FISH FROM BRAZIL
}

\author{
L.E. GUTIERREZ; R.C.M. da SILVA \\ Departamento de Qutmica, ESALQ/USP, C.P. 9, CEP: 13418-900-Piracicaba,SP
}

\begin{abstract}
SUMMARY: Total fat and fatty acid composition of seven fresh-water and nine marine fish commercially important in Brazil were determined. Palmitic acid was the predominant saturated fatty acid in both freshwater and marine fish. In the fat from freshwater fish the total C-16 fatty acids were higher than in marine fish. Oleic acid was the most abundant monounsaturated fatty acid and it was found in higher levels in freshwater fish. The data revealed that most freshwater fish from Brazil examined were a poor source of eicosapentaenoic (20:5) and docosahexaenoic $(22: 6)$ acids. Of the marine fish analysed, only sardine and manjuba could be recommended as a good sources of n-3 fatty acids.
\end{abstract}

Key Words: fatty acids, fish, lipids, ômega-3

\section{COMPOSIÇÃO EM ÁCIDOS GRAXOS DE PEIXES COMERCIALMENTE IMPORTANTES DO BRASIL}

\begin{abstract}
RESUMO: Foram determinadas a gordura total e a composiçâo em ácidos graxos de sete espécies de peixes de água doce e nove espécies de peixes de água salgada, comercialmente importantes do Brasil. $O$ ácido palmítico foi 0 ácido predominante dentre os saturados tanto nos peixes de água doce como salgada. Na gordura dos peixes de água doce, o total de ácidos graxos com 16 carbonos foi superior aos de água salgada. $O$ ácido oleico foi o mais abundante dos monoinsaturados e foi encontrado em maiores niveis nos peixes de água doce. Os dados revelaram que a maioria dos peixes de água doce são fontes deficientes dos ácidos eicosapentaenóico (20:5) e docosahexaenóico (22:6). Dos peixes de agua salgada analisados, apenas sardinha e manjuba podem ser recomendados como fontes adequadas de ácidos graxos n-3.
\end{abstract}

Descritores: ácidos graxos, peixes, lipídios, ômega-3

\section{INTRODUCTION}

There is much information available on the fatty acid composition of the lipids present in cold water fish species of the North Hemisphere while very little is published on lipids of freshwater and marine fish species from Brazil.

The main characteristic difference in freshwater fish is the higher levels of C-16 and C18 acids and the lower levels of $\mathrm{C}-20$ and $\mathrm{C}-22$ acids when compared to marine fish, and these differences are mainly due to the dietary fat (ACKMAN，1967; VISWANATHAN-NAIR \& GOPAKUMAR, 1978). However recent reports indicate that freshwater fish contain relatively large amounts of eicosapentaenoic and docosahexaenoic acids (AGREN et al., 1987; WANG et al., 1990).

As it has been pointed out by STANSBY (1973) fish can be included in diets for at least three reasons: 1) as a general source of nutritional components; 2) as low-fat, high protein food; and 3 ) as source of polyunsaturated fatty acids.
The consumption of marine fish and other seafood is beneficial in reducing the risk of cardiovascular disorders and it has been demonstrated in studies with eskimos (GLOMSET, 1985; DYERBERG,1986; LEAF \& WEBER, 1988).

DYERBERG et al. (1978) have already pointed out that dietary enrichment with eicosapentaenoic acid could protect the organism from thrombosis.

NELSON et al. (1991) have reported that a salmon diet, high in $\mathrm{n}-3$ fatty acids, does not affect bleeding times, but changes the fatty acid composition of the plasma and platelet membrane lipids. AKOH \& HEARNSBERGER (1991), on the other hand, verified that salmon diets prolonged bleeding times. Another beneficial effect of $n-3$ fatty acids is the reduction of serum triglyceride and very low-density lipoprotein levels (BRONSGEEST-SCHOUTE et al., 1981).

Dietary fish oil is more effective than alpha-linolenic acid in altering tissue phospholipid 
fatty acid composition and modulating eicosanoid metabolism (WHELAN et al., 1991).

The beneficial effects of fish oil fatty acids have been reviewed by HEROLD \& KINSELLA (1986) and GAUDETTE \& HOLUB, (1991).

This paper discusses the fatty acid composition of seven species of freshwater fish and nine species of marine fish commercially important in Brazil.

\section{EXPERIMENTAL PROCEDURES}

Sampling of fish. The fish collected included seven freshwater fish from Brazilian rivers and nine saltwater species from the Atlantic coast. All fish were purchased from a fish market in Piracicaba,SP. (Brazil) area. Triplicate samples were taken from the center of the fresh and frozen fish fillets by removing 10-12 $\mathrm{g}$ pieces of flesh.

Extration of lipids. Lipids were extracted from 10$12 \mathrm{~g}$ samples using the procedure of FOLCH et al. (1957) by homogenizing them in a mechanical blender with a mixture of chloroform and methanol $(2: 1 \mathrm{v} / \mathrm{v})$. To prevent oxidation, crystals of hydroquinone were added to all samples. The chloroform extract was evaporated at $55^{\circ} \mathrm{C}$ under vacuum and the residue weighed.

Preparation of methyl esters. Following the extraction of lipids from the various fish tissues, methyl esters of fatty acids were prepared for subsequent use in gas-liquid chromatography. Lipid extracts were converted to their methyl esters according to HARTMAN \& LAGO (1973).

Gas-liquid chromatography. Analysis of methyl esters was performed on a CG-17 Gas Chromatograph (CG Instrumentos, São Paulo, Brazil), equipped with a flame ionisation detector. A stainless steel column, $2 \mathrm{~m} \times 5 \mathrm{~mm}$, packed with chromosorb W coated with $18 \%$ (by wt) of diethylene glycol succinate (DEGS) was used. The operating conditions were as follows: column temperature, $195^{\circ} \mathrm{C}$; sample vaporizer temperature, $225^{\circ} \mathrm{C}$; detector temperature, $245^{\circ} \mathrm{C}$. The carrier gas used was nitrogen, at a flow rate of 40 of $\mathrm{mL} / \mathrm{min}$. Injected sample sizes were in the range 2.0 - $3.0 \mu 1$. Fatty acids were identified by comparison with the retention time of standards and by equivalent chain lenght (ACKMAN, 1969). No effort was made to determine the positions of double bonds. The peak areas were determined by triangulation and the results were expressed in weight $\%$ of the total amount of fatty acids.

\section{RESULTS AND DISCUSSION}

The fatty acid composition of the various freshwater fish are listed in TABLE 1. The data show that the amount of constituent fatty acids varied among species. This fact can be seen by the range of the following fatty acids: $1.67-11.49 \%$ myristic, 2.89 - $20.65 \%$ palmitoleic, 4.51 $11.12 \%$ stearic, 11.63 - $27.87 \%$ oleic, 1.55 9.75\% eicosapentaenoic and $1.37-21.81 \%$ docosahexaenoic acids.

Fatty acids from freshwater fish were more saturated (29.79-39.68\%) than marine fish (23.64-34.76\%), and palmitic acid was the most important, as it has been pointed out by GOPAKUMAR \& NAIR (1972) for Indian marine fish.

Certain differences are apparent in the fatty acid composition of the freshwater fish compared with the marine species (TABLE 2). The $\mathrm{C}-16+\mathrm{C}-18$ acid contents were higher for the freshwater fish with lower level of eicosapentaenoic and docosahexaenoic acids. These data confirmed earlier observations of ACKMAN (1967), VISWANATHAN-NAIR \& GOPAKUMAR (1978) and GUNSTONE et al. (1978).

Higher levels of palmitoleic acid have been described as a characteristic of freshwater fish (ACKMAN, 1967). Comparing TABLES 1 and 2, it can be seen that only sardine had levels higher than $9 \%$ among marine fish, while in freshwater fish only pintado and piramutaba had levels lower than $9 \%$. Higher levels of palmitic, palmitoleic and oleic acids have already been related for mandi, a Brazilian freshwater fish, by ANDRADE \& LIMA (1979).

With the exception of sardine, in all marine fish, docosahexaenoic acid was found in higher levels than eicosapentaenoic acid. These data confirmed earlier observations of GRUNGER et al. (1964) and GUNSTONE et al. (1978). As it can be seen from TABLE 3, freshwater fish presented very low amount of 20:5 and 22:6 acids in the flesh lipids when compared to marine fish, although pintado and piramutaba showed high levels of these fatty acids in their fat (TABLE 1), probably due to their diets (carnivorous fish).

The fish flesh fat is lower than $10 \%$ (TABLE 3) and it can be considered normal among marine species (HEARN et al., 1987). 
TABLE 1 - Fatty acid composition of freshwater fish (wt\% of the total amount of fatty acids).

\begin{tabular}{|c|c|c|c|c|c|c|c|}
\hline \multirow[b]{2}{*}{ Fatty acid } & \multicolumn{7}{|c|}{ FISH } \\
\hline & Corimbatá & Lambari & Mandi & Piava & Pintado & Piramutaba & Traíra \\
\hline $12: 0$ & ND & 1.1 & ND & ND & ND & ND & ND \\
\hline $14: 0$ & 3.2 & 11.5 & 1.9 & 1.7 & 2.1 & 3.6 & 2.8 \\
\hline $14: 1$ & 1.1 & ND & 1.5 & ND & ND & ND & ND \\
\hline $16: 0$ & 21.8 & 22.8 & 19.6 & 27.4 & 21.5 & 23.0 & 23.1 \\
\hline $16: 1$ & 20.6 & 17.5 & 12.6 & 9.4 & 2.9 & 6.5 & 13.1 \\
\hline $16: 2$ & 1.5 & 1.0 & ND & ND & ND & ND & ND \\
\hline 18:0 & 4.5 & 4.6 & 7.7 & 5.7 & 10.2 & 11.1 & 8.4 \\
\hline $18: 1$ & 16.7 & 11.6 & 27.9 & 26.9 & 14.2 & 13.1 & 18.4 \\
\hline $18: 2$ & 3.7 & 2.7 & 5.7 & 7.5 & 0.5 & 1.1 & 4.7 \\
\hline $20: 0$ & ND & 0.4 & ND & ND & 0.1 & 0.6 & ND \\
\hline $18: 3+20: 1$ & 7.6 & 4.7 & 9.2 & 12.3 & 0.3 & 0.7 & 4.4 \\
\hline $20: 2$ & 0.4 & 1.1 & 0.9 & 0.5 & ND & ND & 0.1 \\
\hline 22:0 & 0.3 & 0.4 & 0.5 & 0.6 & ND & ND & 0.8 \\
\hline $22: 3+22: 1$ & 4.4 & 3.2 & 5.0 & 2.3 & 7.8 & 6.1 & 8.3 \\
\hline $20: 4$ & 1.5 & 1.4 & 0.2 & 1.0 & 0.1 & ND & 0.3 \\
\hline $20: 5$ & 5.6 & 2.6 & 1.5 & 2.0 & 7.5 & 9.7 & 3.4 \\
\hline $22: 3$ & 0.4 & 0.4 & 1.4 & ND & 0.8 & 0.9 & 1.2 \\
\hline $22: 4$ & 0.8 & 1.5 & 0.3 & ND & 3.5 & 3.0 & 2.2 \\
\hline $22: 5$ & 2.0 & 1.5 & 1.8 & 1.2 & 3.4 & 5.9 & 1.6 \\
\hline $22: 6$ & 3.0 & 6.8 & 2.0 & 1.4 & 21.8 & 14.3 & 7.1 \\
\hline$x_{1} *$ & 1.0 & 0.2 & ND & ND & 1.0 & 0.3 & ND \\
\hline $\mathrm{X}_{2} *$ & ND & 2.9 & ND & ND & 2.3 & ND & ND \\
\hline * peaks n & identified & & not detec & & & & \\
\hline
\end{tabular}

According to LEAF \& WEBER (1988) there are no good data available to recommend a desirable amount of fish oil. However AKOH \&
HEARNSBERGER (1991) verified that a consumption of $1-2 \mathrm{~g} /$ day of $n-3$ polyunsaturated fatty acids prolonged significantly bleeding and 
TABLE 2 - Fatty acid composition of marine fish (wt\% of the total amount of fatty acids).

\begin{tabular}{|c|c|c|c|c|c|c|c|c|c|}
\hline \multirow[b]{2}{*}{$\begin{array}{l}\text { Fatty } \\
\text { acid }\end{array}$} & \multicolumn{9}{|c|}{ FISH } \\
\hline & Abroteia & Cabrinha & Cavalinha & Manjuba & Pescada & Porquinho & Ray & Sardine & Tuna \\
\hline $12: 0$ & ND & ND & ND & ND & ND & ND & ND & 0.1 & ND \\
\hline $14: 0$ & 1.1 & 1.8 & 7.6 & 3.7 & 0.9 & 0.8 & 1.0 & 9.8 & 2.0 \\
\hline $14: 1$ & ND & ND & 0.5 & ND & ND & ND & ND & 0.4 & ND \\
\hline $16: 0$ & 17.2 & 22.8 & 14.1 & 24.2 & 15.5 & 17.8 & 17.1 & 16.2 & 22.7 \\
\hline $16: 1$ & 1.3 & 5.1 & 5.0 & 5.7 & 8.5 & 3.7 & 8.1 & 11.3 & 3.4 \\
\hline 18:0 & 8.0 & 8.1 & 2.6 & 6.6 & 7.2 & 8.8 & 10.1 & 1.3 & 9.5 \\
\hline $18: 1$ & 12.8 & 15.7 & 14.4 & 16.8 & 18.8 & 15.7 & 16.9 & 9.8 & 13.7 \\
\hline $18: 2$ & 0.4 & 0.6 & 2.0 & 0.9 & 0.9 & 1.1 & 0.2 & 4.3 & 0.8 \\
\hline $20 \cdot 0$ & ND & ND & ND & 0.2 & ND & ND & ND & 0.3 & 0.2 \\
\hline \multicolumn{10}{|l|}{$18: 3+$} \\
\hline $20: 1$ & 0.6 & 1.5 & 11.1 & 1.1 & 0.9 & 3.0 & 2.6 & 2.6 & 1.2 \\
\hline $20: 2$ & ND & 0.6 & 4.2 & 0.8 & ND & 0.5 & 0.8 & 2.5 & 0.4 \\
\hline $22: 0$ & ND & ND & ND & ND & ND & ND & 0.1 & ND & ND \\
\hline \multicolumn{10}{|l|}{$22: 3+$} \\
\hline $22: 1$ & 7.1 & 5.4 & 16.9 & 1.8 & 4.9 & 7.6 & 14.6 & 4.8 & 3.6 \\
\hline $20: 4$ & ND & 0.2 & ND & 0.7 & ND & ND & 0.4 & 0.2 & ND \\
\hline $20: 5$ & 11.4 & 10.1 & 6.2 & 8.8 & 7.7 & 8.6 & 4.1 & 24.2 & 7.8 \\
\hline $22: 3$ & 1.1 & 1.2 & 1.3 & 0.7 & ND & 0.9 & 3.2 & ND & ND \\
\hline $22: 4$ & 1.6 & 1.3 & ND & 1.2 & 0.9 & 0.7 & 1.5 & 2.4 & 1.6 \\
\hline $22: 5$ & 3.2 & 4.3 & 1.0 & 2.8 & 2.9 & 3.3 & 5.1 & 2.2 & 0.4 \\
\hline $22: 6$ & 34.3 & 21.2 & 13.0 & 23.7 & 19.2 & 26.6 & 11.6 & 6.5 & 32.5 \\
\hline$X_{1} *$ & ND & ND & ND & ND & 11.6 & 0.9 & 0.8 & 0.8 & ND \\
\hline$X_{2}{ }^{*}$ & ND & ND & ND & ND & ND & ND & 1.6 & 0.1 & ND \\
\hline
\end{tabular}

* peaks not identified

clotting times and BRONSGEEST-SCHOUTE et al. (1981) related that in groups receiving $2.27 \mathrm{~g} /$ day there was a reduction of cholesterol levels. The results of the marine and freshwater fish comparisons establish that only sardine and manjuba could achieve levels of 1 $2 \mathrm{~g}$ of $20: 5+22: 6$ acids in a normal diet. 
TABLE 3 - Eicosapentaenoic (EPA) and docosahexaenoic (DHA) acids contents per 100g serving.

\begin{tabular}{cccc}
\hline \hline & & \multicolumn{2}{l}{ FATTY ACIDS, $\mathrm{g} / 100 \mathrm{~g}$ wet muscle } \\
\cline { 2 - 4 } FISH & $\mathrm{g} / 100 \mathrm{~g}$ wet muscle & EPA & DHA \\
\hline Freshwater & & & \\
Corimbatá & 6.75 & 0.30 & 0.16 \\
Lambari & 4.58 & 0.09 & 0.25 \\
Mandi & 7.08 & 0.09 & 0.11 \\
Piava & 9.75 & 0.15 & 0.11 \\
Pintado & 0.41 & 0.02 & 0.07 \\
Piramutaba & 0.47 & 0.04 & 0.05 \\
Traíra & 1.27 & 0.03 & 0.07 \\
Marine & & & 0.15 \\
Abrotéia & 0.56 & 0.05 & 0.17 \\
Cabrinha & 1.00 & 0.08 & 0.87 \\
Cavalinha & 8.43 & 0.41 & 1.08 \\
Manjuba & 5.94 & 0.42 & 0.17 \\
Pescada & 1.11 & 0.07 & 0.16 \\
Porquinho & 0.78 & 0.05 & 0.07 \\
Ray & 0.72 & 0.02 & \\
Sardine & 7.88 & 0.52 & \\
Tuna & & & 0.41 \\
\hline \hline
\end{tabular}

\section{REFERENCES}

ACKMAN, R.G. Characteristics of the fatty acid composition and biochemistry of some fresh-water fish oils and lipids in comparison with marine oils and lipids. Comparative Biochemistry and Physiology, v.22, p.907-922, 1967.

ACKMAN, R.G. Gas-liquid chromatograph of fatty acids and esters. Methods in Enzymology, San Diego, v.14, p.392-381, 1969.

AGREN, J.; MUJE, P.; HANNINEN, O.; HERRANEN, J.; PENTTILA, I. Seasonal variations of lipid fatty acids of boreal freshwater fish species. Comparative Biochemistry Physiology, v.88b, n.3,p.905-909,1987
AKOH, C.C. \& HEARNSBERGER, J.O. Effect of catfish and salmon diet on platelet phospholipid and blood clotting in healthy men. Journal of Nutritional Biochemistry, Atoncham, v.2, p.329-333, 1991.

ANDRADE, M.O. \& LIMA, U.A. The effects of sason and processing on the lipids of mandi (Pimelodus clarias, Bloch), a Brazilian freshwater fish. CONFERENCE OF THE TORRY RESEARCH STATION, 1979, Aberdeen. Farnhan: Fishing Newsbcoks, 1979, p.387-393.

BRONSGEEST-SCHOUTE, H.C.; VAN GENT, C.M.; LUTEN, J.B.; RUTTER, A. The effect of various intakes of $w-3$ fatty acids on the blood lipid composition in healthy human subjects. American 
Journal of Clinical Nutritrion, Bethesda, v.34, p.1752-1757, 1981.

DYERBERG, J.; BANG, H.O.; STOFFERSEN, E.; MONCADA, S.; VANE,J.R. Eicosapentaenoic acid and prevention of thrombosis and atherosclerosis ? Lancet, London, v.1, p.117-119, 1978.

DYERBERG, J. Linolenate-derived polyunsaturated fatly acids and prevention of atherosclerosis. Nutrition Review, Toronto, v.44, n.4, p.125-134, 1986.

FOLCH, J.; LEES, M.; SLOANE-STANOLEY, G.H. A simple method for the isolation and purification of total lipids from animal tissues. Joumal of Biological Chemistry, Bethesda, v.226, p.497-509, 1957.

GAUDETTE, D.C.; HOLUB, B.J. Docosahexaenoic acid (DHA) and platelet reactivity. Journal of Nutricional Biochemistry, Stonehan, v.2, p.116-121, 1991.

GLOMSET, J.A. Fish, fatty acids and human health. New England Journal of Medicine, Waltham, v.312, n.19, p.1253-1254, 1985.

GOPAKUMAR, K.; NAIR, M.R. Fatty acid composition of eight species of Indian marine fish. Journal of the Science of Food and Agriculture, Essex, v.23, p.493-496, 1972 .

GRUGER, E.H.; NELSON, R.W.; STANSBY, M.E. Fatty acid composition of oils from 21 species of marine fish, freshwater fish and shellfish. Journal of the American Oil Chemists'Society, Champaign, v.41, n.10, p.662-667, 1964.

GUNSTONE, F.D.; WIJESUNDERA, R.C.; SCRIMGEOUR, C.M. The component acids of lipids from marine and freshwater species with special reference to furan-containing acids. Journal of the Science of Food and Agriculture, Essex, v.29, p.539-550, 1978 .

HARTMAN, L. \& LAGO, R.C.A. Rapid preparation of fatty acid methyl esters from lipids. Laboratory. Practice, London, v.22, p.475-476, 1973.
HEARN, T.L.; SGOUTAS, S.A.; HEARN, J.A.; SGOUTAS, D.S. Polyunsaturated fatty acids and fat in fish flesh for selecting species for health benefits. Journal of Food Science, Chicago, v.52, n.5, p.1209$1211,1987$.

HEROLD, P.M.; KINSELLA, J.E. Fish oil consumption and decreased risk of cardiovascular disease: a comparison of findings from animal and human feeding trials. American Journal of Clinical Nutrition. Bethesda, v.43, p.566-598, 1986.

LEAF, A.; WEBER, P.C. Cardiovascular effects of n-3 fatty acids. New England Journal of Medicine, Waltham, v.318, n.9, p.549-557, 1988.

NELSON, G.J.; SCHMIDT, P.C.; CORASH, L. The effect of a salmon diet on blood clotting platelet aggregation and fatty acids in normal adult men. Lipids, Champaign, v.26, n.2, p.87-96, 1991.

STANSBY, M.E. Polyunsaturates and fat in fish flesh. Journal of the American Dietetic Association, Chicago, v.63, p.625-630, 1973.

VISWANATHAN-NAIR, P.G.; GOPAKUMAR, K. Fatty acid compositions of 15 species of fish from tropical waters. Journal of Food Science, Chicago, v.43, p.1162-1164, 1978 .

WANG, Y.J.; MILLER, L.A.; PERREN, M.; ADDIS,P.B. Omega-3 fatty acids in Lake Superior fish. Journal of Food Science, Chicago, v.55, n.1, p.71-76, 1990.

WHELAN, J.; BROUGHTON, K.S.; KINSELLA, J.E. The comparative effects of dietary alpha-linolenic acid and fish oil on 4- and 5- series leukotriene formation in vivo. Lipids, Champaign, v.26, n.2, p.119-126, 1991.

Received May 26, 1993

Accepted July 16, 1993

Enviado para publicação em 26.05.93

Aceito para publicação em 16.07 .93 